\title{
PHOSPHORUS ZONING FROM SECONDARY OLIVINE IN MANTLE XENOLITH FROM MIDDLE ATLAS MOUNTAINS (MOROCCO, AFRICA): IMPLICATIONS FOR CRYSTAL GROWTH KINETICS
}

\author{
Mavrogonatos K. ${ }^{1,2}$, Flemetakis S. ${ }^{1,2}$, Papoutsa A. ${ }^{1}$, Klemme S. ${ }^{3}$, Berndt J. ${ }^{3}$, \\ Economou G. ${ }^{4}$, Pantazidis A. ${ }^{1}$, Baziotis $I^{1}{ }^{1}$ and Asimow P.D. ${ }^{5}$ \\ ${ }^{1}$ Department of Natural Resources Management and Agricultural Engineering, Agricultural \\ University of Athens, Iera Odos 75, 11855 Athens, Greece, ibaziotis@aua.gr \\ ${ }^{2}$ Faculty of Geology and Geoenvironment, National and Kapodistrian University of Athens, \\ Panepistimiopolis, Zografou 15784 Athens, Greece \\ ${ }^{3}$ Institut für Mineralogie, Universität Münster, Corrensstrasse. 24, 48149, Münster, Germany \\ ${ }^{4}$ Institute of Geology and Mineral Exploration, Olympic Village Acharnae, Athens, Greece, P.C. \\ 13677 \\ ${ }^{5}$ California Institute of Technology, Division of Geological and Planetary Sciences, Pasadena \\ California 91125, USA
}

\begin{abstract}
Mantle xenolith samples in contact with basalt flows were collected from the Tafraoute maar in Morocco. Discrete melt veins are present in one xenolith sample, crosscutting primary layering and foliation. We used both optical microscopy and electron microprobe analysis to characterize the glasses and minerals in the melt veins. The melt veins consist of glass and crystals of olivine, clinopyroxene, plagioclase, spinel and apatite. The olivine in the melt veins is quite distinct from the same mineral within the matrix due to its characteristic P-enriched rims (up to 0.3 wt.\%). Correlations between Al and $P$, as well as experimentally determined partition coefficient for $P$, point towards non-equilibrium partitioning during rapid crystal growth at the end of crystallization.

Keywords: melt vein; boundary layer enrichment; Tafraoute maar.

\section{Пєрí $\eta \psi \eta$}

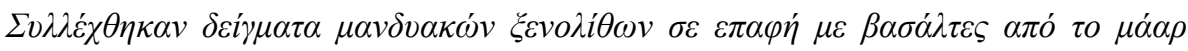

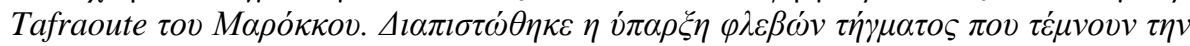

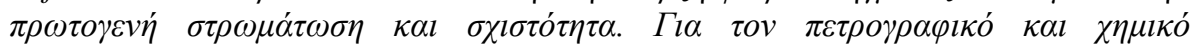

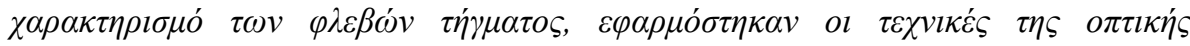

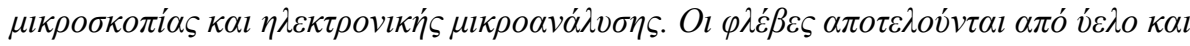

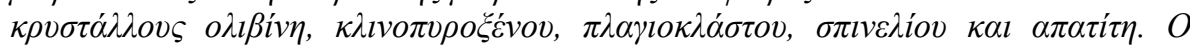

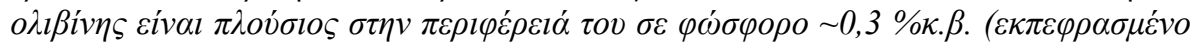
$\omega \varsigma \mathrm{P}_{2} \mathrm{O}_{5}$ ). Correlations between $\mathrm{Al}$ and $\mathrm{P}$, as well as experimentally determined partition coefficient for $P$, point towards non-equilibrium partitioning during rapid

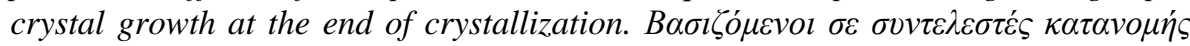

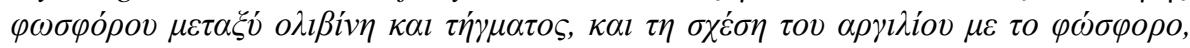




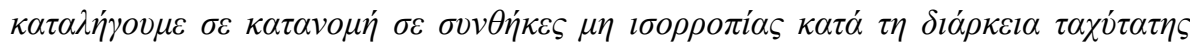

$\alpha \nu \alpha \dot{\pi} \tau v \xi \bar{\eta} \varsigma \sigma \tau o \tau \dot{\lambda} \lambda o \varsigma \tau \eta \varsigma \kappa \rho v \sigma \tau \alpha \dot{\lambda} \lambda \omega \sigma \sigma \eta \varsigma$.

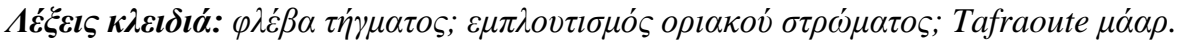

\section{Introduction}

Mantle xenoliths provide critical information on the geological history of the Earth's mantle lithosphere, including - in principle - the durations and rates of chemical and thermal events. The mineral chemistry of such xenoliths, and in particular the presence of phosphorus $(\mathrm{P})$-a moderately incompatible and very slowly diffusing element - may preserve the history of mineral growth and constrain timescales of pre-eruption petrogenetic processes (e.g. Boesenberg and Hewins, 2010). Prich zones in olivine may reflect incorporation of $\mathrm{P}$ in excess of equilibrium partitioning during rapid growth, in which case zoning patterns primarily record crystal growth rate variations, or they may be related to other processes such as non-equilibrium incorporation, melt composition, temperature, oxygen fugacity, or apatite saturation conditions (Toplis and Caroll, 1995; Milman-Barris et al., 2008; Mallmann et al., 2009; Boesenberg and Hewins, 2010; Grant and Kohn, 2013; Welsch et al., 2014).

In this study we report the results of detailed micro-scale analyses of the constituent minerals and glass in and around melt veins from one xenolith sample from the Tafraoute maar (Morocco). Sample MA-1 contains spinel-bearing lherzolite and orthopyroxenite layers, crosscut by veins that are dominated by glass and secondary phases. Although, the host lava is present on the margins of the recovered hand sample specimen, it was not included in our thin section. However, the xenolithbearing flows in the broad Tafraoute maar area include nephelinites, basanites and alkaline basalts (El Azzouzi et al., 1999, 2010; El Messbahi et al., 2015) and we expect our xenolith's host to be in this compositional range.

We used both optical microscopy and electron microprobe (EMP) analysis to characterize the glasses and minerals in the melt veins. This paper focuses most intently on the exotic secondgeneration P-rich zoned olivines found in the melt veins. We examine whether the $\mathrm{P}$ concentrations are anomalous given the overall budget of $\mathrm{P}$ in the melt veins. Finally, we propose a zonation model for the olivine to infer constraints on the growth processes and to assess the extent of disequilibrium relative to the associated glass.

\section{Sampling areas - Description}

\subsection{Geological Setting}

The Tafraoute maar is located in Morocco (Figs. 1, 2), situated at the NW termination of the NESW North Middle Atlas Fault, which separates the "folded" Middle Atlas to the southeast from the "tabular" Middle Atlas to the northwest. The tectonic framework of the area is associated with a NESW oriented strip of thin lithosphere that is expressed at the surface by a series of intraplate alkaline volcanic centers (Lenaz et al., 2014 and references therein). The Middle Atlas basaltic province comprises the largest and youngest volcanic fields (strombolian cones and maars) in Morocco with an age range spanning from Miocene to Quaternary (0.6-0.5 Ma). The Tafraoute maar may be a distal and attenuated expression of the mantle upwelling centered on the Bou Ibalghatene maar, about $45 \mathrm{~km}$ to the southwest, and bordered by the Middle Atlas Fault on the southeast. The Tafraoute maar is thought to record various stages of deformation associated with decompression and lithospheric thinning (El Messbahi et al., 2015).

\subsection{Mantle xenoliths}

Several of the middle Atlas maar outcrops contain ultramafic xenoliths with a variety of lithologies, including a full spectrum of fertility from harzburgites through spinel lherzolites and wehrlites to pyroxenites. We collected several mantle xenoliths during the post-conference field trip to the 
Middle Atlas after the $6^{\text {th }}$ Orogenic Lherzolite Conference in Marrakech, 2014. The criteria for the selection of the studied xenolith were freshness and integrity of specimen and the presence of an obvious melt vein crosscutting the layering of the xenolith.

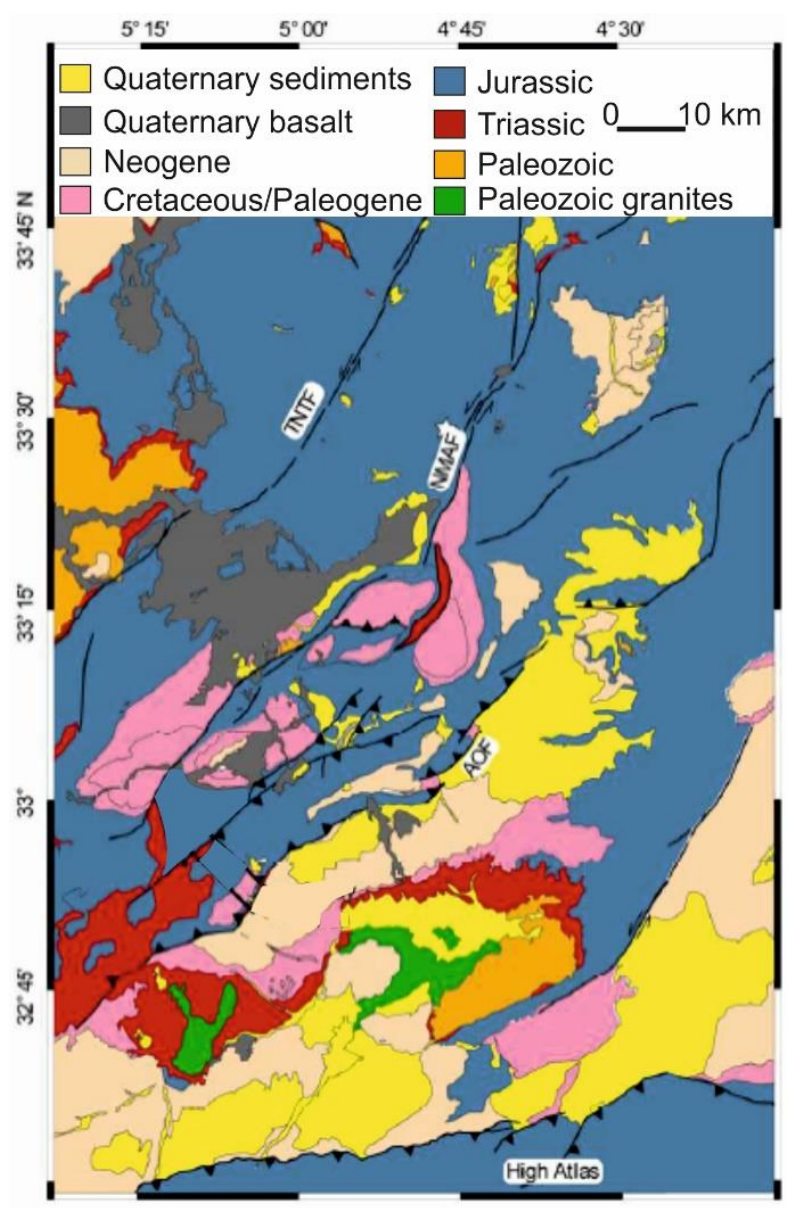

Figure 1 - Geologic map of the Middle Atlas Mountains. Labeled structures include AOF Ait Oufella Fault, TNTF - Tizi-n-Tretten Fault, and NMAF - North Middle Atlas Fault. Study area is outlined by a black box. Figure adapted from Gomez et al. (1998).

\section{Analytical Methods}

\subsection{Major elements}

Major element compositions of minerals were determined in polished thin section using a JEOL JXA8530F EMP equipped with five wavelength-dispersive spectrometers (WDS) and one energydispersive spectrometer (EDS) at the Institut für Mineralogie, University of Münster, Germany. All analyses used $15 \mathrm{kV}$ accelerating potential. For minerals, a $20 \mathrm{nA}$ beam current and $20 \mathrm{~s}$ counting time on peak position were used. For glass analyses, a slightly defocused beam with $5 \mu \mathrm{m}$ diameter and $10 \mathrm{~s}$ counting time were used, in order to avoid volatilization of lighter elements such as $\mathrm{Na}$. Natural minerals were used as standards: albite $(\mathrm{Na}, \mathrm{Si}, \mathrm{Al})$, wollastonite $(\mathrm{Ca})$, olivine $(\mathrm{Mg})$, almandine $(\mathrm{Fe})$, spessartine $(\mathrm{Mn})$, orthoclase $(\mathrm{K})$, apatite $(\mathrm{P})$, rutile $(\mathrm{Ti})$, chromite $(\mathrm{Cr})$ and Ni-oxide (Ni). Representative olivine and glass compositions are given in Table 1. 


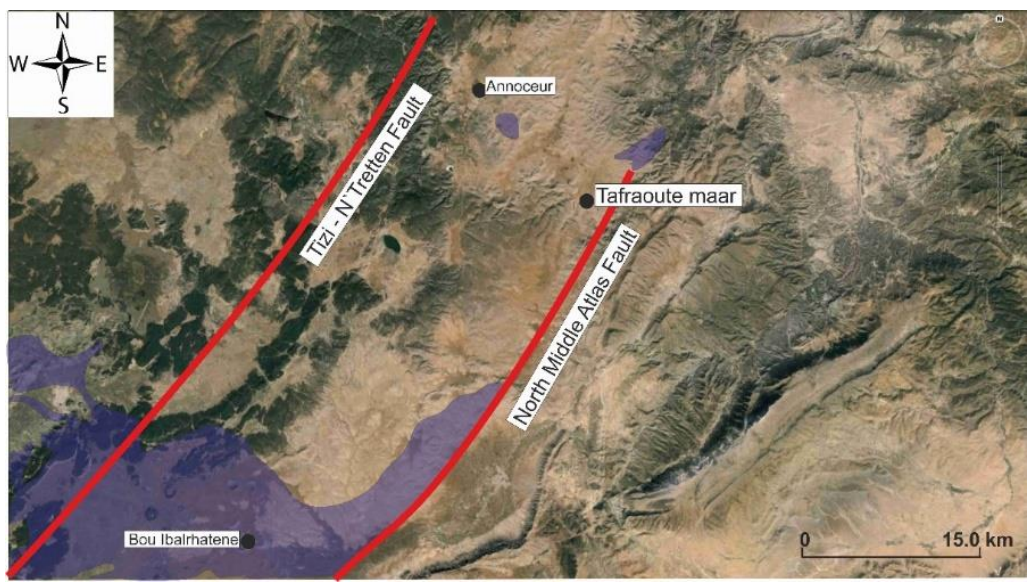

Figure 2 - Sketch map (from Google Earth) showing the location of Tafraoute maar $\left(33^{\circ} 31^{\prime} 10.20^{\prime \prime} \mathrm{N}-4^{\circ} 41^{\prime} 37.60^{\prime \prime} \mathrm{W}\right)$. Purple fields indicate lava flows. Red lines are major faults.

Table 1 - Representative olivine and glass compositions (in wt.\%) from the studied mantle xenolith.

\begin{tabular}{|c|c|c|c|c|c|c|c|c|c|c|c|c|}
\hline Olivine & $\begin{array}{c}\text { Ol1- } \\
8^{*}\end{array}$ & $\begin{array}{c}\text { Ol1- } \\
9 *\end{array}$ & $\begin{array}{c}\text { O12- } \\
9 *\end{array}$ & $\begin{array}{l}\text { Ol1- } \\
13^{*}\end{array}$ & $\begin{array}{l}\text { Ol- } \\
2 * *\end{array}$ & $\begin{array}{l}\text { Ol- } \\
3^{* * *}\end{array}$ & Glass & 12 & 14 & 16 & 20 & 25 \\
\hline $\mathrm{SiO}_{2}$ & 37.9 & 37.1 & 39.2 & 38.9 & 40.6 & 40.5 & $\mathrm{SiO}_{2}$ & 45.6 & 49.6 & 46.2 & 46.4 & 45.2 \\
\hline $\mathrm{TiO}_{2}$ & 0.06 & 0.12 & 0.05 & 0.06 & - & 0.01 & $\mathrm{TiO}_{2}$ & 2.65 & 2.84 & 3.14 & 3.5 & 3.3 \\
\hline $\mathrm{Al}_{2} \mathrm{O}_{3}$ & 0.04 & 0.15 & 0.02 & 0.19 & - & 0.01 & $\mathrm{Al}_{2} \mathrm{O}_{3}$ & 16.8 & 19.3 & 16.9 & 17.8 & 17.1 \\
\hline $\mathrm{Cr}_{2} \mathrm{O}_{3}$ & 0.04 & 0.01 & 0.02 & 0.01 & 0.01 & - & $\mathrm{Cr}_{2} \mathrm{O}_{3}$ & 0.00 & 0.05 & 0.00 & 0.00 & 0.00 \\
\hline $\mathrm{FeO}$ & 17.9 & 21.9 & 16.3 & 16.0 & 10.5 & 10.1 & $\mathrm{FeO}$ & 9.87 & 8.2 & 10.2 & 8.24 & 8.45 \\
\hline $\mathrm{MnO}$ & 0.33 & 0.42 & 0.25 & 0.30 & 0.19 & 0.18 & $\mathrm{MnO}$ & 0.18 & 0.12 & 0.22 & 0.12 & 0.11 \\
\hline $\mathrm{MgO}$ & 42.7 & 38.3 & 43.3 & 43.8 & 48.9 & 49.4 & $\mathrm{MgO}$ & 2.73 & 1.61 & 2.72 & 1.89 & 2.32 \\
\hline $\mathrm{NiO}$ & 0.11 & 0.12 & 0.18 & 0.35 & 0.37 & 0.32 & $\mathrm{NiO}$ & 0.03 & 0.04 & 0.00 & 0.00 & 0.00 \\
\hline $\mathrm{CaO}$ & 0.43 & 0.45 & 0.23 & 0.31 & 0.02 & 0.03 & $\mathrm{CaO}$ & 7.88 & 6.76 & 7.50 & 8.81 & 9.39 \\
\hline $\mathrm{P}_{2} \mathrm{O}_{5}$ & 0.15 & 0.21 & 0.04 & 0.30 & - & - & $\mathrm{Na}_{2} \mathrm{O}$ & 5.78 & 1.28 & 5.06 & 6.14 & 5.48 \\
\hline Total & 99.6 & 98.7 & 99.5 & 100.1 & $\begin{array}{c}100 . \\
6\end{array}$ & $\begin{array}{c}100 . \\
5\end{array}$ & $\mathrm{~K}_{2} \mathrm{O}$ & 2.32 & 2.26 & 2.06 & 2.23 & 2.37 \\
\hline \multirow{2}{*}{\multicolumn{7}{|c|}{ *: Secondary; **: matrix }} & $\mathrm{P}_{2} \mathrm{O}_{5}$ & 1.52 & 1.10 & 1.45 & 1.15 & 1.33 \\
\hline & & & & & & & Total & 95.4 & 93.1 & 95.4 & 96.3 & 95.0 \\
\hline
\end{tabular}

\section{Petrographic and Analytical Results}

\subsection{Matrix petrography}

The studied mantle xenolith was recovered from the contact with the host lava, which is presumed to be alkalic like other analysed xenolith-bearing lavas in the region. The xenolith contains spinelbearing lherzolite and orthopyroxenite layers displaying a coarse to porphyroclastic texture (Harte, 1975). The lherzolite is amphibole-free, and dominated by euhedral to subhedral olivine crystals and subhedral orthopyroxene and clinopyroxene. The orthopyroxenite layer is composed of large, euhedral to subhedral orthopyroxenes. Some finer-grained areas are composed of small olivine and interstitial spinel crystals.

\subsection{Melt vein and veinlets petrography}

Discrete dark-coloured melt veins about $\sim 100 \mu \mathrm{m}$ wide on average penetrate the lherzolite and orthopyroxenite layers; some of these veins clearly crosscut the foliation and lithologic layering, 
whereas others are parallel to layering (Fig. 3). Lacking analysis of the host lava, we cannot say at this time whether there is a cogenetic relationship between host lava and melt veins in the xenolith.

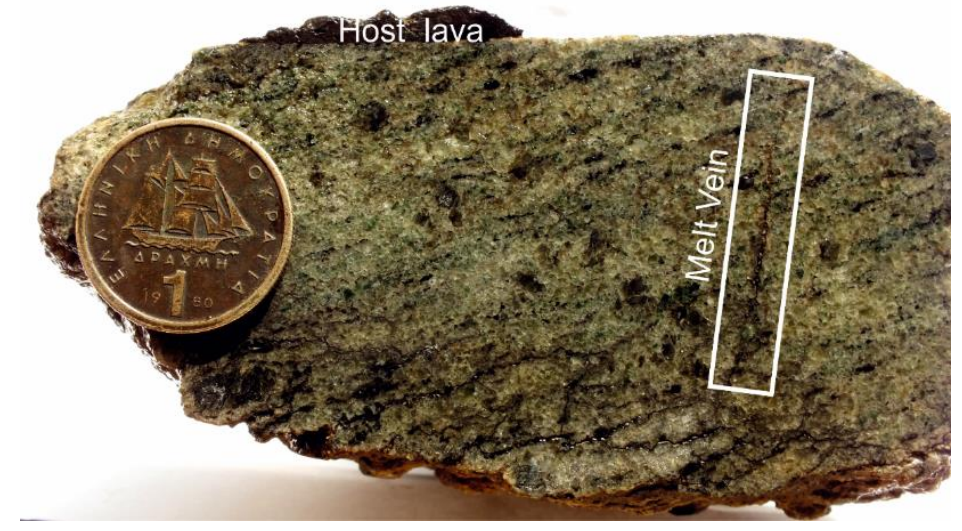

Figure 3 - Hand-specimen image of sample MA-1 xenolith from Tafraoute maar. A melt vein with phosphorus-rich olivines is indicated by the white rectangle.

The studied melt veins are generally composed of olivine (Fig. 4a) + clinopyroxene + plagioclase + spinel + glass \pm apatite. Plagioclase occurs as prismatic, flow-oriented crystals parallel or subparallel to the layering (Fig. 4b). Although some olivine grains are free of inclusions, others may contain rounded glass (quenched melt) inclusions (Fig. 4c) or subhedral inclusions of spinel or ilmenite. The olivines are generally found in contact with plagioclase and glass. The abundance of glass in several studied veins varies from $\sim 5$ to 15 vol. \%; the largest volume fractions are observed only in the large cross-cutting melt vein highlighted in Fig. 3. Where vein glass is in contact with matrix olivine, mineral-melt reaction is indicated by Fe-rich outer rims on the olivine. Spinel shows both anhedral and euhedral shapes and occurs both as inclusions in olivine and as discrete grains associated with plagioclase and glass. Where spinel is in contact with glass, it presents a spongy outer rim and a normal zonation with progressively more Fe-rich compositions towards the rim. Clinopyroxene is present both as isolated subhedral to euhedral crystals within the melt layer and as replacive rims where matrix orthopyroxene and olivine have reacted with the melt. Very fine-grained clinopyroxene crystals indicative of quench (up to $10 \mu \mathrm{m}$ in width and dendritic shape) are also present (Fig. 4d). Apatite is found mostly as very small crystals embedded in glass.

\subsection{Analytical results}

The melt veins contain olivines $\left(\mathrm{Fo}_{72.1-83.4}\right)$ with 0.02-0.3 wt. $\% \mathrm{P}_{2} \mathrm{O}_{5}$; the $\mathrm{P}$-rich olivines $\left(\mathrm{P}_{2} \mathrm{O}_{5}>0.1\right.$ wt.\%) are $\mathrm{Fo}_{75.3}$ to $\mathrm{Fo}_{82.8}$. The glass has variable composition with $\mathrm{P}_{2} \mathrm{O}_{5}$ up to 1.52 wt.\%, $\mathrm{K}_{2} \mathrm{O} 1.65$ 2.37 wt. $\%, \mathrm{CaO}$ 6.39-9.55 wt. \%, $\mathrm{Na}_{2} \mathrm{O}$ 0.78-6.70 wt.\% and $\mathrm{SiO}_{2} 45.2-49.6$ wt.\% (Table 1). In $\mathrm{MgO}$ variation diagrams, the glass compositions appear to display a coherent single trend group for all oxides, with the exception of a discrete low-Na group containing four to six analyses (Fig. 5).

In olivine, $\mathrm{P}$ is correlated negatively with $\mathrm{Si}^{4+}$, poorly with the divalent cations $(\mathrm{Mg}+\mathrm{Fe}+\mathrm{Ca})$ and positively with $\mathrm{Al}^{3+}$ (Fig. 6; $\mathrm{R}$ is $>0.7$ showing that the correlation is statistically significant). These correlations suggest that the predominant substitution is: $2^{\mathrm{IV}} \mathrm{Si}^{4+}={ }^{\mathrm{IV}} \mathrm{P}^{5+}+{ }^{\mathrm{IV}} \mathrm{R}^{3}$, where IV refers to tetrahedral sites and $\mathrm{R}^{3+}$ to trivalent cations like $\mathrm{Al}^{3+}, \mathrm{Cr}^{3+}$ and $\mathrm{Fe}^{3+}$. Furthermore, $\mathrm{P}$ is concentrated mainly at the rim of the olivine, in contact with the surrounding glass. In particular, individual rimrim profiles show maximum $\mathrm{P}_{2} \mathrm{O}_{5}$ content up to $0.25 \mathrm{wt} . \%$ at the rims of the crystals (Fig. 6). 

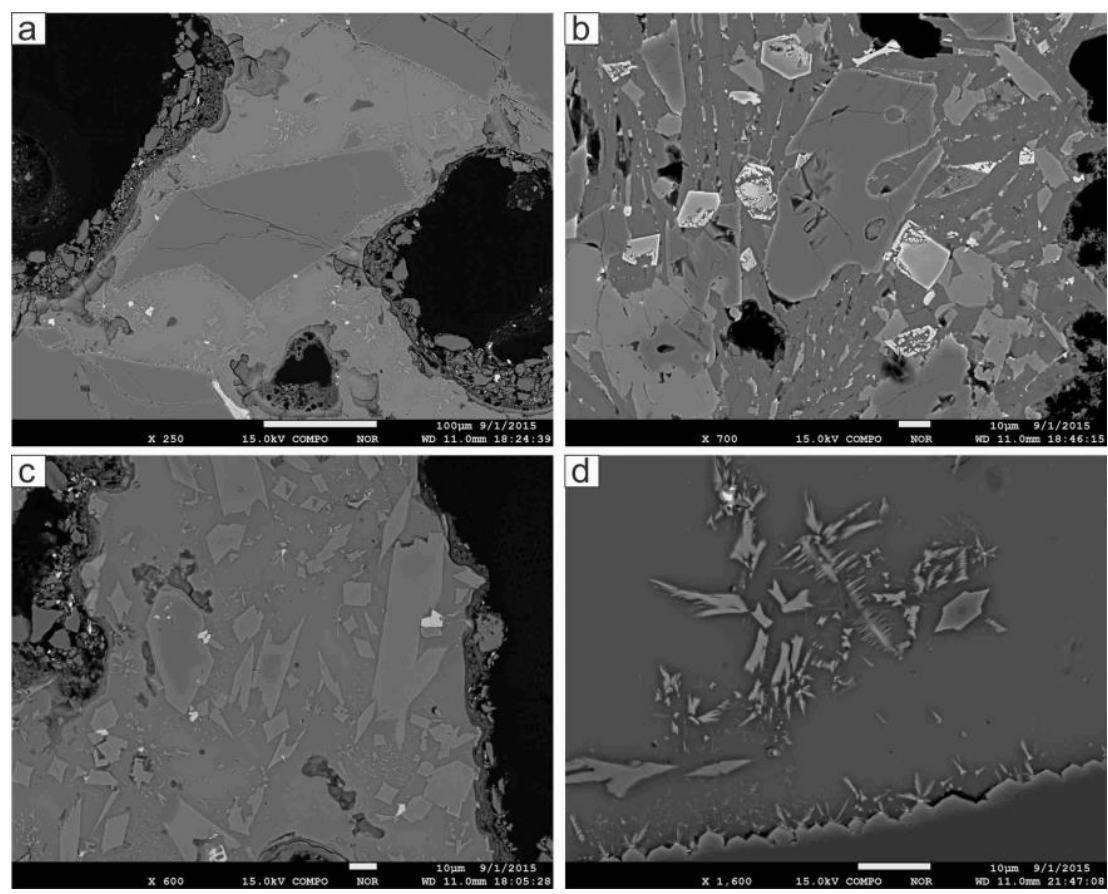

Figure 4 - a) Large P-poor subhedral olivine embedded in melt vein. b) Melt vein with plagioclase as flow-oriented crystals and euhedral zoned spinel. A large subhedral olivine hosts a melt inclusion. c) Small euhedral to subhedral olivine and clinopyroxene crystals in melt vein. At left, an euhedral P-rich olivine with Fe-rich rim, d) Small clinopyroxene quenched crystals in melt vein.

\section{Discussion}

In the literature, $\mathrm{D}_{\mathrm{P}}{ }^{\mathrm{ol} / \mathrm{melt}}$ has been reported in the range 0.02 to 1.6 , with the lowest numbers thought to represent equilibrium conditions and higher values usually attributed to non-equilibrium partitioning via processes such as solute trapping during rapid growth (Reitano et al., 1994; Grant and Kohn 2013). According to Jambon et al. (1992), P-Al-rich areas of olivine may grow in minutes, whereas P-Al-poor zones represent a few weeks. Furthermore, high-resolution X-ray mapping of $\mathrm{P}$ in olivine reveals narrow P-rich bands parallel to rim of the crystals (Fig. 7). The imperfect correlation between $\mathrm{P}$ and $\mathrm{Al}$ in our data implies either diffusive relaxation of $\mathrm{Al}$ gradients or, judging by dynamic experiments (Grant and Kohn, 2013), cooling rates $\sim 1-10^{\circ} \mathrm{C} / \mathrm{h}$ that generate disequilibrium solute trapping of $\mathrm{P}$ but near-equilibrium incorporation of Al. Early-crystallized olivine grew slowly enough to incorporate only quantities of $\mathrm{P}$ consistent with equilibrium partitioning, suggesting that no P-rich boundary layer developed despite the slow diffusion of $\mathrm{P}$ in melts. Afterwards, during crystallization of olivine rim, the process was rapid enough to over-enrich $\mathrm{P}$; the increase in $\mathrm{P}$ at the rim is too large in amplitude and too abrupt to be consistent with simple concentration of $\mathrm{P}$ in a decreasing mass of residual melt (Watson et al., 2015; Baziotis et al., 2016). The apparent partition coefficient between olivine rims and adjacent melt suggests $D_{P}{ }^{\text {ol/melt }}$ in the range $0.13-0.19$. 

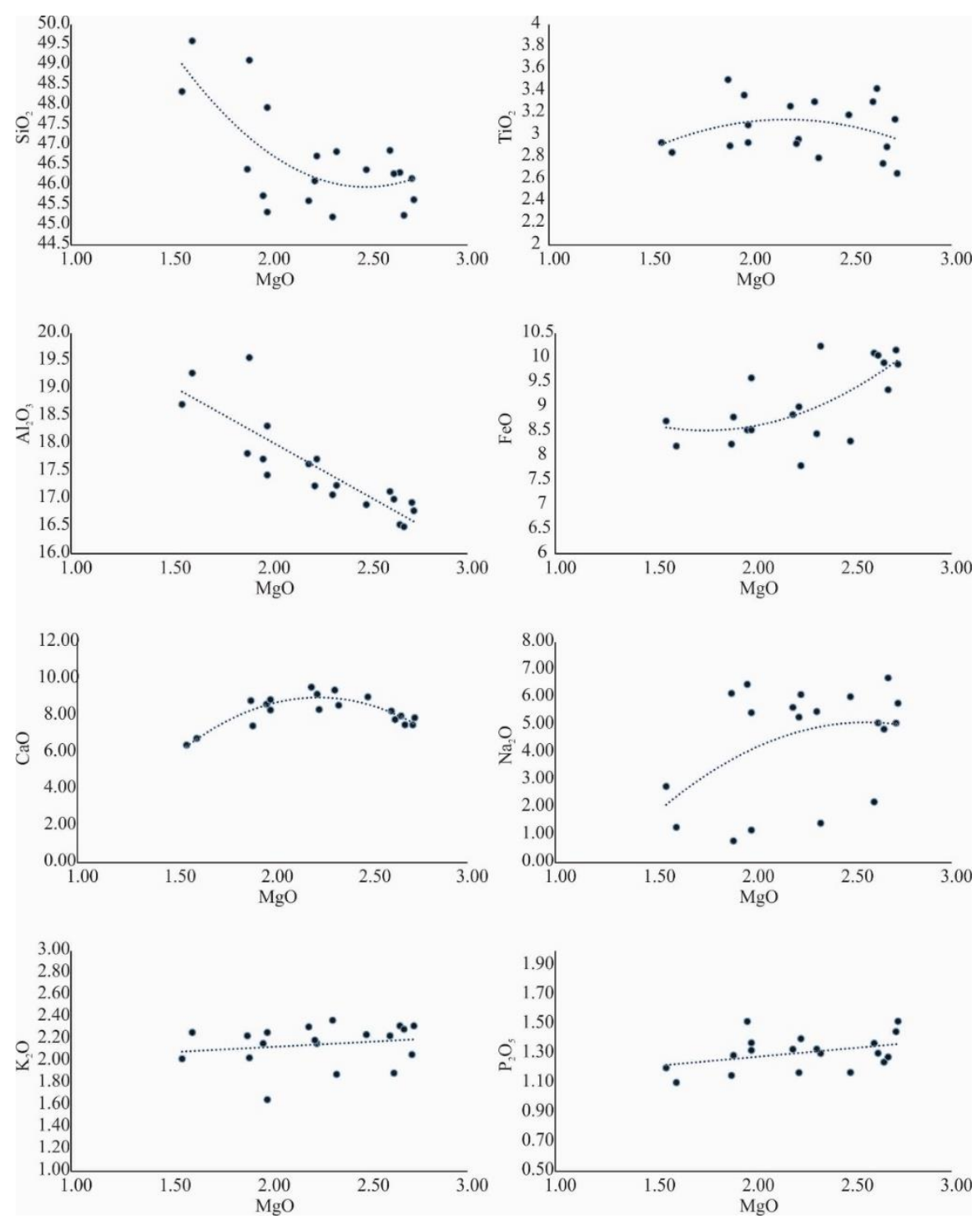

Figure 5 - Glass compositions correlating $\mathrm{MgO}$ with major oxides (all in wt.\%). The dotted lines or curves are linear or quadratic trendlines based on least squares method. 

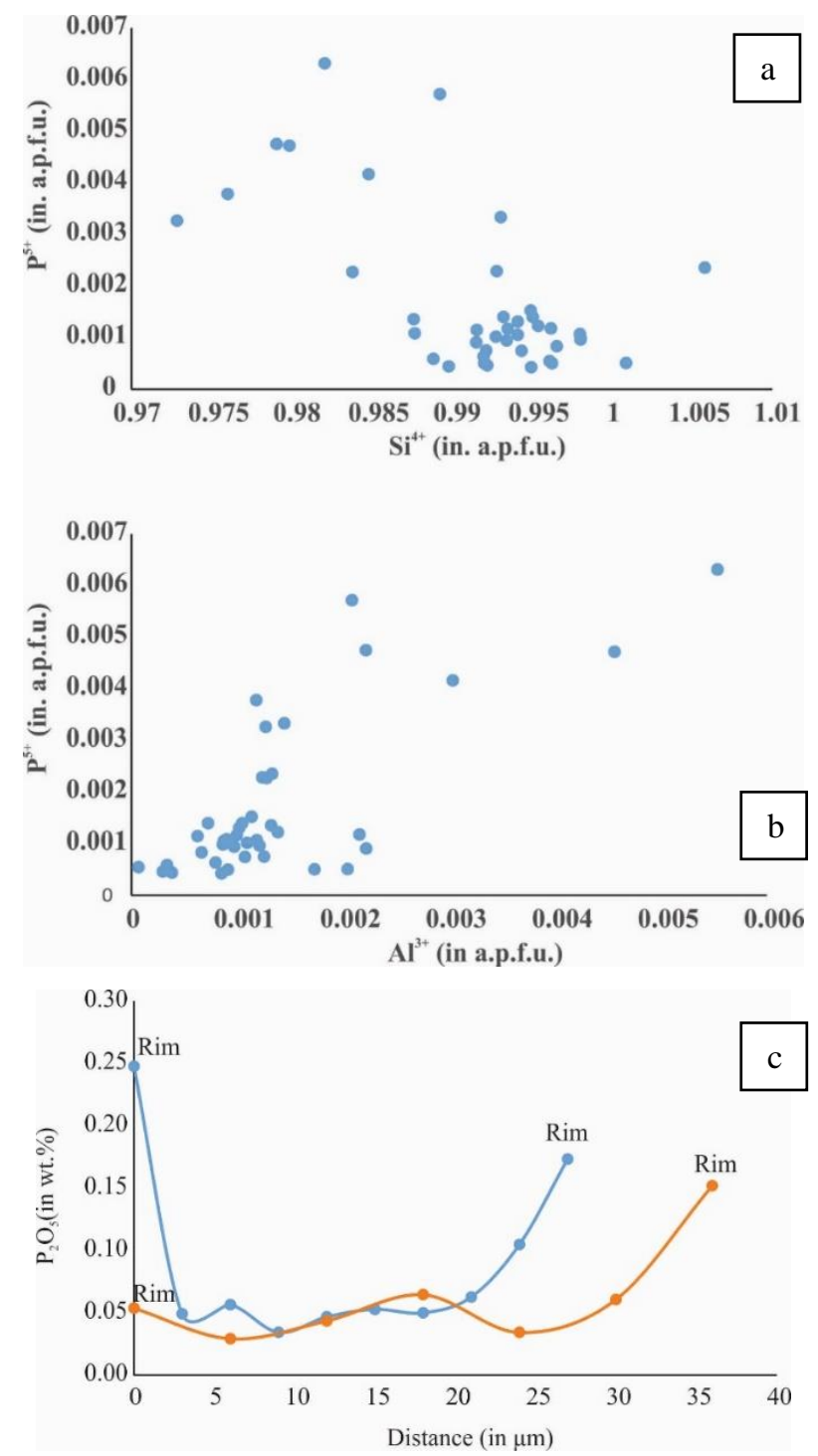

Figure 6 - Correlation of olivine $\mathrm{P}$ with (a) $\mathrm{Si}^{4+}$ and (b) $\mathrm{Al}^{3+}$. (c) Two compositional rim-rim profiles across a particular olivine grain, as indicated in figure 7 (A-B profile in blue; $C$-D profile in orange).

\section{Conclusions}

A mantle xenolith sample was collected in contact with an alkali basalt flow from the Tafraoute maar in Morocco. Melt veins appear to locally crosscut the layering and the foliation of this rock. Within these veins, zoned olivine appears to be P-enriched towards the rims. Correlations between the chemistry of olivine and experimentally determined partition coefficients for $\mathrm{P}$ suggest that crystallization of P-poor olivine cores was rather slow, as to incorporate only minor amounts of this component. Enrichment in $\mathrm{P}$, on the other hand, was facilitated by non-equilibrium partitioning during rapid crystal growth. The latter is further suggested by the imperfect correlation between $\mathrm{P}$ and $\mathrm{Al}$ in olivine. 

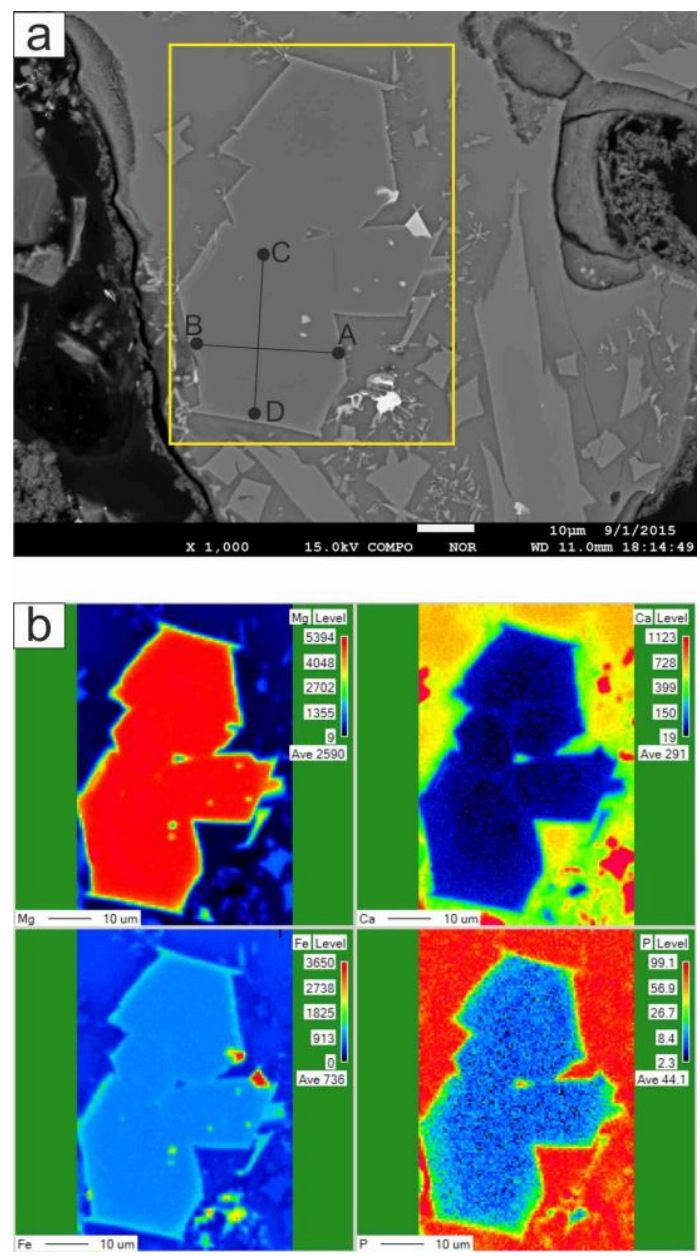

Figure 7 - a) Cluster of P-rich olivine grains embedded in melt vein. b) X-ray maps for Mg, $\mathrm{Ca}, \mathrm{Fe}$, and $\mathrm{P}$ of the olivine indicated in (a). The Ca map delineates grains within the cluster.

\section{Acknowledgments}

I.B. was supported by research funding implemented within the framework of the «IKYDA» programme 242, based on a bilateral agreement between the State Scholarships Foundation (IKY) and Deutscher Akademischer Austausch Dienst. Additional funds to I.B. implemented within the framework of the Action «Supporting Postdoctoral Researchers» of the Operational Program "Education and Lifelong Learning" (Action's Beneficiary: General Secretariat for Research and Technology), and is co-financed by the European Social Fund (ESF) and the Greek State. PDA is supported by the US NSF through award GI-1226270. We would like to thank an anonymous reviewer for his constructive comments and Prof Alexandros Chatzipetros for his editorial handling.

\section{References}

Baziotis, I., Asimow, P.D., Ntaflos, T., Boyce, J.W., McCubbin, F.M., Koroneos, A., Perugini, D., Flude, S., Storey, M., Liu, Y.S., Klemme, S., Berndt, J. and Stolper, E.M., 2016. Phosphorus zoning as a recorder of crystal growth kinetics: application to secondary olivine and pyroxene in mantle xenoliths from Cima Volcanic Field, Journal of Petrology, Under Review. 
Boesenberg, J.S. and Hewins, R.H., 2010. An experimental investigation into the metastable formation of phosphoran olivine and pyroxene, Geochimica et Cosmochimica Acta, 74, 1923-1941.

El Azzouzi, M., Bernard-Griffiths, J., Bellon, H., Maury, R.C., Piqué, A., Fourcade, S., Cotten, J. and Hernandez, J., 1999. Evolution des sources du volcanisme marocain au cours du Néogène, C. R. Acad. Sci. Paris, 329, 95-102.

El Azzouzi, M., Maury, R.C., Bellon, H., Youbi, N., Cotten, J. and Kharbouch, F., 2010. Petrology and K-Ar chronology of the Neogene-Quaternary Middle Atlas basaltic province, Morocco, Bull. Soc. Géol. Fr., 181, 243-257.

El Messbahi, H., Bodinier, J.L., Vauchez, A., Dautria, J.M., Ouali, H. and Garrido, C.J., 2015. Short wavelength lateral variability of lithospheric mantle beneath the Middle Atlas (Morocco) as recorded by mantle xenoliths, Tectonophysics, 650, 34-52.

Gomez, F., Allmendinger, R., Barazangi, M., Er-Raji, A. and Dahmani, M., 1998. Crustal shortening and vertical strain partitioning in the Middle Atlas Mountains of Morocco, Tectonics, 17, 520-533.

Grant, T.B. and Kohn, S.C., 2013. Phosphorus partitioning between olivine and melt: An experimental study in the system $\mathrm{Mg}_{2} \mathrm{SiO}_{4}-\mathrm{Ca}_{2} \mathrm{Al}_{2} \mathrm{Si}_{2} \mathrm{O}_{9}-\mathrm{NaAlSi}_{3} \mathrm{O}_{8}-\mathrm{Mg}_{3}\left(\mathrm{PO}_{4}\right)_{2}$, American Mineralogist, 98, 1860-1869.

Harte, B., 1977. Rock nomenclature with particular relation to deformation and recrystallization textures in olivine-bearing xenoliths, The Journal of Geology, 85, 279-288.

Jambon, A., Lussiez, P., Clocchiatti, R., Weisz, J. and Hernandez, J., 1992. Olivine growth rates in a tholeiitic basalt: An experimental study of melt inclusions in plagioclase, Chemical Geology, 96(3), 277-287.

Lenaz, D., Youbi, N., De Min, A., Boumehdi, M.A. and Abbou, M.B., 2014. Low intra-crystalline closure temperatures of $\mathrm{Cr}$-bearing spinels from the mantle xenoliths of the Middle Atlas Neogene-Quaternary Volcanic Field (Morocco): Mineralogical evidence of a cooler mantle beneath the West African Craton, American Mineralogist, 99(2-3), 267-275.

Mallmann, G., O'Neill, H.C.St. and Klemme, S., 2009. Heterogeneous distribution of phosphorus in olivine from otherwise well-equilibrated spinel peridotite xenoliths and its implications for the mantle geochemistry of lithium, Contributions to Mineralogy and Petrology, 158, 485504.

Milman-Barris, M.S., Beckett, J.R., Baker, M.B., Hofmann, A.E., Morgan, Z., Crowley, M.R., Vielzeuf, D. and Stolper, E., 2008. Zoning of phosphorus in igneous olivines, Contributions to Mineralogy and Petrology, 155, 739-765.

Reitano, R., Smith, P.M. and Aziz, M.J., 1994. Solute trapping of group III, IV, and V elements in silicon by an aperiodic stepwise growth mechanism, Journal of Applied Physics, 76(3), 15181529.

Toplis, M.J. and Carroll, M.R., 1995. An experimental study of the influence of oxygen fugacity on Fe-Ti oxide stability, phase relations, and mineral-melt equilibria in ferro-basaltic systems, Journal of Petrology, 36, 1137-1170.

Watson, E.B., Cherniak, D.J. and Holycross, M.E., 2015. Diffusion of phosphorus in olivine and molten basalt, American Mineralogist, 100, 2053-2065.

Welsch, B., Hammer, J. and Hellebrand, E., 2014. Phosphorus zoning reveals dendritic architecture of olivine, Geology, 42, 867-870. 